\title{
STUDY OF SEXUALLY TRANSMITTED INFECTIONS IN PREGNANT WOMEN AND ITS EFFECTS ON PREGNANCY OUTCOME
}

\author{
Shabana Sultan ${ }^{1}$, Kirti Rachwani²
}

${ }^{1}$ Associate Professor, Department of Obstetrics and Gynaecology, Gandhi Medical College, Bhopal.

${ }^{2}$ Resident, Department of Obstetrics and Gynaecology, Gandhi Medical College, Bhopal.

\section{ABSTRACT}

\section{AIMS}

1. The study aimed to evaluate presence of sexually transmitted infections in pregnant women and to study its distribution in relation to age, parity, social class, habitat and education.

2. To study symptomatology and signs of different sexually transmitted infections in pregnancy and its adverse effects on maternal and pregnancy outcome.

\section{MATERIAL AND METHODS}

Sexually transmitted infections in Department of Obstetrics and Gynaecology, Gandhi Medical College, Sultania Zanana Hospital, Bhopal, during 15 months' period from August 2010 to October 2011 were studied. The individual records of all sexually transmitted infections occurring during the study period of 15 months were extracted from patient's case notes and hospital record registers.

\section{RESULTS}

In year August 2010 to October 2011, this study is done on 500 pregnant women in all trimesters of pregnancy, out of which 195 (39\%) women were found positive for sexually transmitted infections and among this positive women, maximum i.e. 102 (52.3\%) women were in age group 20-24 years followed by 61 (31.2\%) women in 25-29 years of age group. Among positive found women $131(67.17 \%)$ women were urban dwellers. The highest number of sexually transmitted infections occurred among multigravida 107 (54.87\%). Most of the women who were having infection were illiterate 97 (49.74\%), belonged to low socioeconomic class 147 (75.47\%), not using any form of contraception 142 (78.82\%), has poor genital hygiene 153 (78.5\%). And out of 195 infected women, maximum 155 (79.48\%) were having one or another symptoms and most common complaint with which they present is discharge per vaginum 54 (27.6\%) followed by discharge+itching 47 (24.1\%). Out of 195 women found positive for STI, 21 (10.76\%) were having viral infection, 119 (61.03\%) were having non-viral (Bacterial/fungal or parasitic) STI and 55 (28.2\%) had mixed infections and among pregnancies with STI's 98 (54.7\%) had adverse pregnancy outcome.

\section{CONCLUSIONS}

This study has demonstrated that frequency of sexually transmitted infections is unacceptably high and this continues to have an impact on pregnancy outcome. Integration of antenatal screening services for these infections and treatment during antenatal care should be prioritized.

\section{KEYWORDS}

Sexually Transmitted Infections, Pregnant Women.

HOW TO CITE THIS ARTICLE: Sultan S, Rachwani K. Study of sexually transmitted infections in pregnant women and its effects on pregnancy outcome. J. Evolution Med. Dent. Sci. 2016;5(41):2553-2556, DOI: 10.14260/jemds/2016/596

\section{INTRODUCTION}

According to world health organization, sexually transmitted infections is defined as 'Infections that are spread primarily through person-to-person sexual contact.' There are more than 30 different sexually transmissible bacteria, viruses and parasites.

It is estimated that 340 million curable Sexually Transmitted Diseases (STDs) like HIV, chlamydia, genital herpes, genital warts, gonorrhoea, hepatitis, syphilis and trichomoniasis occurs globally every year, most of them occurs in developing countries. ${ }^{1,2}$

Biologically, women are more susceptible to most

Financial or Other, Competing Interest: None.

Submission 04-04-2016, Peer Review 29-04-2016,

Acceptance 05-05-2016, Published 23-05-2016.

Corresponding Author:

Dr. Shabana Sultan,

Associate Professor,

Department of Obstetrics and Gynaecology,

Gandhi Medical College,

Bhopal.

E-mail: shaby_2k2@yahoo.com

DOI: $10.14260 /$ jemds $/ 2016 / 596$ sexually transmitted diseases than men, because of the greater mucosal surface exposed to the greater quantity of pathogens during sexual intercourse. As a result of such factors, most STDs including HIV infection are transmitted more readily from men to women than from women to men ${ }^{3}$. Women with STDs are more likely to be asymptomatic than men and therefore are less likely to seek treatment for them resulting in chronic infections with more long-term complications and sequelae. The social stigma associated with STIs and seeking care leads to thousands of women suffer physically as well as socially or die needlessly from consequences of these infections including infertility and pregnancy wastage, cervical cancers, ectopic pregnancy, acute and chronic infections and puerperal infections.

RTI and STIs are highly prevalent among pregnant women in developing countries and cause significant maternal and perinatal morbidity. They have been associated with number of adverse pregnancy outcomes including abortion, stillbirth, preterm delivery, premature rupture of membranes, low birth weight, postpartum sepsis, ophthalmia neonatorum, neonatal blindness, neonatal pneumonia and congenital infections.2,4 Apart from this STI/RTI have been shown to 
facilitate transmission of HIV.5,6 Many STIs and RTIs are transmitted to the neonate by vertical transmission, thus exposing the newborn to these dreadful diseases even before birth.

This has resulted in peculiar affection of baby not otherwise seen in adults like congenital syphilis, HIV embryopathy, juvenile onset recurrent papillomatosis, chronic hepatitis, hepatocellular carcinoma at younger age and full blown AIDS at early stage. Prematurity and LBW are among the leading causes of perinatal mortality in resource poor settings. $^{2}$ Early diagnosis and treatment for most Reproductive Tract Infection (RTIs) and STDs can lead to decrease in morbidity and mortality due to these illnesses. This study was conducted to know the leading causes and outcomes of STIs at a tertiary care centre, so that corrective steps can be taken to reach a goal.

\section{MATERIAL AND METHODS}

This hospital based randomized, prospective, observational study was carried out in the Department of Obstetrics and Gynaecology, Sultania Zanana Hospital, Gandhi Medical College, Bhopal, on 500 pregnant women, during period of 15 months from August 2010 to October 2011. Total 500 pregnant women in all trimesters of pregnancy attending SZH, which is a tertiary care centre at Bhopal draining vast population were recruited. Sample size was calculated by taking projected prevalence of STI/RTI $30-50 \%$ and the permissible level of error as $10 \%$, which comes out to be 400 .

\section{RESULTS}

This study is done on total 500 pregnant women in all trimesters of pregnancy, attending Sultania Zanana Hospital, Bhopal, which is a tertiary care centre at Bhopal draining vast population were recruited.

\begin{tabular}{|c|c|c|}
\hline & Number & Percentage \\
\hline $\begin{array}{c}\text { Group-I (Pregnant Women } \\
\text { Positive) }\end{array}$ & 195 & $39 \%$ \\
\hline $\begin{array}{c}\text { Group-II (Pregnant Women } \\
\text { Negative) }\end{array}$ & 305 & $61 \%$ \\
\hline \multicolumn{2}{|c|}{$\begin{array}{c}\text { Table 1: Distribution of Pregnant Women } \\
\text { According to the Presence and Absence of STI }\end{array}$} \\
\hline
\end{tabular}

Table 1 shows that out of 500 pregnant women, 195 (39\%) women were found positive for sexually transmitted infections.

\begin{tabular}{|c|c|c|c|c|}
\hline \multirow{2}{*}{$\begin{array}{c}\text { Age Groups } \\
\text { (In Years) }\end{array}$} & \multicolumn{2}{|c|}{ Group-I } & \multicolumn{2}{c|}{ Group- II } \\
\cline { 2 - 5 } & No. & $\mathbf{\%}$ & No. & \% \\
\hline $15-19$ & 7 & 3.58 & 17 & 5.57 \\
\hline $20-24$ & 102 & 52.30 & 173 & 56.72 \\
\hline $25-29$ & 61 & 31.28 & 88 & 28.85 \\
\hline 30.34 & 20 & 10.25 & 21 & 06.88 \\
\hline $35-39$ & 04 & & 04 & 01.31 \\
\hline $40-45$ & 01 & 0.51 & 02 & 00.65 \\
\hline Total & $\mathbf{1 9 5}$ & & $\mathbf{3 0 5}$ & \\
\hline \multirow{2}{*}{ Habitat } & \multicolumn{2}{|c|}{ Group-I } & \multicolumn{2}{c|}{ Group-II } \\
\cline { 2 - 5 } & No. & \% & No. & \% \\
\hline Urban & 131 & 67.17 & 199 & 65.24 \\
\hline Rural & 64 & 32.82 & 106 & 34.75 \\
\hline Total & $\mathbf{1 9 5}$ & $\mathbf{1 0 0}$ & $\mathbf{3 0 5}$ & $\mathbf{1 0 0}$ \\
\hline
\end{tabular}

\begin{tabular}{|c|c|c|c|c|}
\hline \multirow{2}{*}{ Gravidity } & \multicolumn{2}{|c|}{ Group-I } & \multicolumn{2}{c|}{ Group-II } \\
\cline { 2 - 5 } & No. & $\mathbf{\%}$ & No. & \% \\
\hline Primi & 88 & 45.12 & 158 & 51.8 \\
\hline Multi & 107 & 54.87 & 147 & 48.20 \\
\hline Total & $\mathbf{1 9 5}$ & $\mathbf{1 0 0 \%}$ & $\mathbf{3 0 5}$ & $\mathbf{1 0 0 \%}$ \\
\hline $\begin{array}{r}\text { Table 2: Distribution of Pregnant Women } \\
\text { (Group-I \& II) According to their Age }\end{array}$ \\
\hline
\end{tabular}

Table 2 show that out of 500 pregnant women studied, maximum 102 (52.3\%) women in group-I were in 20-24 years' age group followed by 61 (31.2\%) women in 25-29 years' age group. Therefore, mean age of women in group-I was 24.8 years.

In group-II, maximum 173 (56.7\%) women belonged to 20-24 years' age group followed by 88 (28.8\%) in $25-29$ years of age group.

Table 2 tells that out of 500 antenatal women, 131 (67.17) women of group-I were urban dwellers and 64 $(32.82 \%)$ were rural dwellers.

Table 2 show that out of 500 pregnant women studied, maximum 107 (54.87\%) women of group-I were multigravida and 88 (45.12\%) women were primi gravida. While in GroupII, maximum 158 (51.8\%) were primi gravida.

\begin{tabular}{|c|c|c|c|c|}
\hline \multirow{2}{*}{$\begin{array}{c}\text { Genital } \\
\text { Hygiene }\end{array}$} & \multicolumn{2}{|c|}{ Group-I } & \multicolumn{2}{c|}{ Group-II } \\
\cline { 2 - 5 } & No. & $\mathbf{\%}$ & No. & $\mathbf{\%}$ \\
\hline Good & 42 & 21.5 & 262 & 86 \\
\hline Poor & 153 & 78.5 & 43 & 14 \\
\hline Total & $\mathbf{1 9 5}$ & & $\mathbf{3 0 5}$ & \\
\hline \multicolumn{3}{|c|}{ Table 3: Distribution of Pregnant Women in Both } \\
Groups According to Genital Hygiene Practices \\
\hline
\end{tabular}

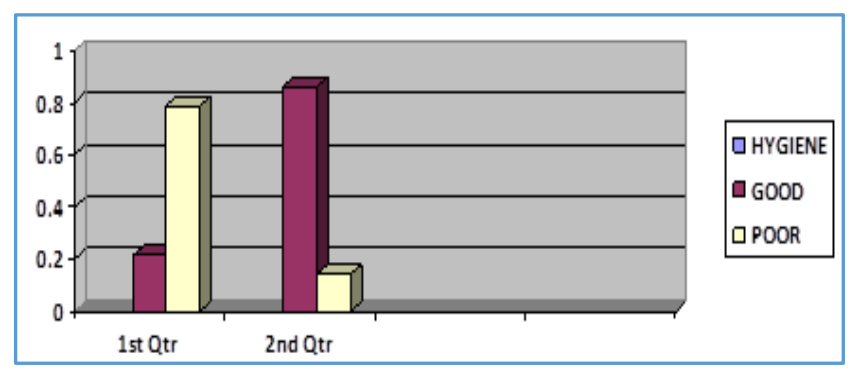

Table 3 shows that in Group-I maximum i.e. 153 (78.5\%) women has poor genital hygiene, while in Group-II good hygiene practices were observed in most i.e. 262 (86\%) and 43 $(14 \%)$ had poor hygiene. Difference was statistically highly significant for genital hygiene $(\mathrm{p}<0.01)$.

\begin{tabular}{|c|c|c|c|c|c|c|}
\hline \multirow{2}{*}{ Contraceptive } & \multicolumn{2}{|c|}{ Group-I } & \multicolumn{2}{c|}{ Group-II } & \multirow{2}{\text{Z}}{$\begin{array}{c}\text { P } \\
\text { value }\end{array}$} \\
\cline { 2 - 6 } & No. & $\mathbf{\%}$ & No. & $\mathbf{\%}$ & val \\
\hline None & 142 & 72.82 & 66 & 21.64 & 5.30 & $<0.01$ \\
\hline Barrier & 11 & 5.64 & 172 & 56.39 & 15.1 & $<0.01$ \\
\hline IUCD & 30 & 15.38 & 22 & 7.21 & 2.857 & $<0.01$ \\
\hline OCP & 12 & 6.15 & 45 & 14.75 & 3.39 & $<0.01$ \\
\hline Total & $\mathbf{1 9 5}$ & $\mathbf{1 0 0}$ & $\mathbf{3 0 5}$ & $\mathbf{1 0 0}$ & & \\
\hline \multicolumn{7}{|c|}{$\begin{array}{c}\text { Table 4: Distribution of Both Groups According } \\
\text { to History of Contraceptive Practice }\end{array}$} \\
\hline
\end{tabular}




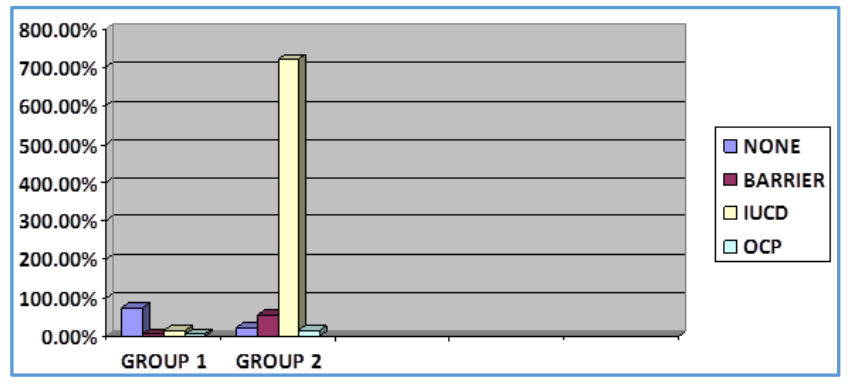

Group-I, most 142 (78.82\%) women were not using any form of contraceptives. In Group-II, 172 (56.39\%) women opted for barrier; 22 (7.21\%) women using IUCD, 45 (14.75\%) had OCP. Statistical difference was highly significant for all variables.

\begin{tabular}{|c|c|c|}
\hline Trimester & No. & Percentage \\
\hline First & 45 & 9 \\
\hline Second & 143 & 28.6 \\
\hline Third & 312 & 62.4 \\
\hline \multicolumn{3}{|c|}{ Table 5: Distribution of Both } \\
Groups According to Trimester \\
\hline
\end{tabular}

Table 5 tells that among 500 pregnant women 45 women (9\%) were enrolled in first trimester, 143 (28.6\%) in second and $312(62.4 \%)$ women were enrolled in the third trimester.

\begin{tabular}{|c|c|c|c|c|}
\hline \multirow{2}{*}{} & \multicolumn{2}{|c|}{ Group-I } & \multicolumn{2}{c|}{ Group-II } \\
\cline { 2 - 5 } & No. & \% & No. & \% \\
\hline Symptomatic & 155 & 79.48 & 47 & 15.40 \\
\hline Asymptomatic & 40 & 20.5 & 258 & 84.59 \\
\hline Total & $\mathbf{1 9 5}$ & & $\mathbf{3 0 5}$ & \\
\hline Table 6: Distribution of Both Groups According to \\
Presence or Absence of any Symptom \\
\hline
\end{tabular}

Out of 195 in Group-I, maximum 155 (79.48\%) were having one or another symptom, $40(20.51 \%)$ women were asymptomatic. In Group-II, maximum women were asymptomatic.

\section{DISCUSSION}

Out of 500 women studied, 195 (39\%) women forming GroupI were found positive for sexually transmitted infections; 305 (61\%) women found negative for STIs. Similar results were observed in studies from the developing world.

\begin{tabular}{|c|c|c|}
\hline Author & Year & Prevalence \\
\hline Marai W. $^{6}$ & 2001 & $40-54 \%$ \\
\hline Gupta. $^{7}$ & 2002 & $37.7 \%$ \\
\hline Ranjan. $^{8}$ & 2003 & $37 \%$ \\
\hline \multicolumn{2}{|c|}{ Table 7: Comparison with Other Studies } \\
\hline
\end{tabular}

\section{Age}

In present study, $424(84.8 \%)$ of women belong to 20-29 years' age group. This is most fertile period of women's life. Among 195 infected women Group-I, 163 (83.6\%) were belonging to age group 20-29 years, mean age was found to be 24.8 in Group-I and 24.18 in Group-II. Other studies also show the same thing.

\begin{tabular}{|c|c|c|}
\hline Author & Year & Age \\
\hline Govender et al $^{9}$ & 1996 & 24 \\
\hline Ranjan. $^{8}$ & 2003 & $20-29$ \\
\hline N. Swarnalatha. $^{10}$ & 2007 & $20-25$ \\
\hline \multicolumn{2}{|c|}{ Table 8: Comparison with Other Studies } \\
\hline
\end{tabular}

\section{Education}

In present study, presence of STI was found to be higher in illiterate women $(49.74 \%)$ and this difference is statistically highly significant $(\mathrm{p}<0.001)$. It showed a decreasing trend with increase in level of education. Our result is similar with the findings of their studies.

\begin{tabular}{|c|c|c|}
\hline Author & Year & \% of STI in Illiterate \\
\hline N. Swarnalatha. ${ }^{10}$ & 2007 & 34 \\
\hline \multicolumn{3}{|c|}{ Table 9: Comparison } \\
\hline
\end{tabular}

\section{Socio-Economic Status}

In present work, majority of infected women i.e. 75.4\% belonged to lower socio-economic status and same is shown by other studies.

\begin{tabular}{|c|c|c|}
\hline Author & Year & $\begin{array}{c}\text { \% of Women in Lower Socio- } \\
\text { Economic Status }\end{array}$ \\
\hline $\begin{array}{c}\text { N. } \\
\text { Swarnalatha. } 10\end{array}$ & 2007 & 69.1 \\
\hline
\end{tabular}

\section{Contraceptive Pills}

In present study, among 195 women found positive for STIs, $142(72.8 \%)$ women never used any form of contraception. This is shown by other studies.

\begin{tabular}{|c|c|c|c|}
\hline Author & Year & $\begin{array}{c}\text { No. of } \\
\text { Women on } \\
\text { Which Study } \\
\text { is Done }\end{array}$ & $\begin{array}{c}\text { No (\%) of Women } \\
\text { Not Used } \\
\text { Contraceptives }\end{array}$ \\
\hline $\begin{array}{c}\text { NO Farell et } \\
\text { al }^{11}\end{array}$ & 1989 & 193 & $125(65 \%)$ \\
\hline $\begin{array}{c}\text { N } \\
\text { Swarnalatha. }\end{array}$ & 2007 & & $60 \%$ \\
\hline Sharma et al 10 & 2009 & & $50 \%$ \\
\hline
\end{tabular}

\section{CONCLUSION}

Out of total 500 women, 195 (39\%) were positive for various sexually transmitted infections (Group-I). While 305 (61\%) women were uninfected (Group-II). In Group-I, 45.2\% women had normal pregnancy outcome, 34\% women had abortion, preterm labour or premature rupture of membrane, 37 (20.6\%) babies had low birth weight, pneumonia or conjunctivitis. The study has demonstrated that frequency of STI/RTI is unacceptably high and these continue to have an impact on pregnancy outcome, integration of antenatal screening services for these infections and treatment during antenatal care should be prioritized. There is an urgent need of affordable, rapid point of care, screening tests for STI screening in resource constrained antenatal care setting, integration of antenatal screening services for these infections and provision of syndromic management for other STI in antenatal clinics should be focused and high rate of STI in the population could justify a more aggressive strategy incorporating periodic presumptive treatment to rapidly reduce prevalence.

\section{REFERENCES}

1. World health organization: Global prevalence and incidence of selected curable sexually transmitted infection: Overview and estimated Geneva: WHO, 2001.

2. Mullick S, Watson Jones, Beksinka M, et al. Sexually transmitted infection in pregnancy: prevalence, impact on pregnancy outcomes, and approach to treatment in developing countries. Sex trans infect 2005;81:294-302. 
3. Jeffcoates principles of gynaecology. Chapter 19, Infection including sexually transmitted infections $7^{\text {th }}$ ed;308-32.

4. Gray RH, Wabwire Mangen F, Kigozi G, et al. Randomised trail of presumptive sexually transmitted disease therapy during pregnancy in rakai Uganda. Am J Obstet Gynaecol 2001;185(5):1209-17.

5. Taha TE, Gray RH. Genital tract infection and perinatal transmission of HIV. Ann N Y Acad Sci 2000;918:84-98.

6. Marai W, Hiller SL, Ecehenback DA. Epidemiology and outcomes associated with moderate to heavy candida colonization during pregnancy. East african medical journal 2001;78:581-5.

7. Vineeta Gupta, Biswaswaroop Chatterjee, Devendra Prasad. Prevalence of sexually transmitted infections among reproductive age group women. Indian Journal Obstet and Gynaecol 2002;52(1).
8. Roochika Ranjan, Sharma AK, Geeta Mehta. Evolution of WHO diagnostic algorithm for reproductive tract infections among married women. Indian journal of community medicine 2003;28(2).

9. Govender L, Hoosen AA, Moodley J, et al. Bacterial vaginosis and associated infections in pregnancy. International journal of Gynaecology and Obstetrics 1996;55(1):23-8.

10. Swarnalatha N, Sridevi B. Prevalance of RTI/STI among reproductive age women in urban slums of Tirupati town, Andhra Pradesh. Health popul perspect issues 2007;30(1):56-70.

11. Farell NO, Hoosen AA, Kharsany AB. Sexually transmitted pathogens in pregnant women in rural south African community. Genitourinary med 1989;65(4):276-80.

12. Savita Sharma, Gupta BP. The prevalence of reproductive tract infections and sexually transmitted disease among married women in reproductive age group in rural area. Indian journal of community medicine 2009;34(1):62-4. 